\title{
Graph Edge
}

National Cancer Institute

\section{Source}

National Cancer Institute. Graph Edge. NCI Thesaurus. Code C75923.

A connection between nodes in a graph. 